\title{
The Potential of some Plant Extracts as Radical Scavengers and Dipeptidyl Peptidase-4 Inhibitors
}

\author{
Lateef A. Malik ${ }^{1 *}$ \\ Ghazi M. Aziz ${ }^{1}$ \\ Ali H. Ad'hiah'
}

Received 9/8/2018, Accepted 11/12/2018, Published 17/3/2019

This work is licensed under a Creative Commons Attribution 4.0 International License.

\begin{abstract}
:
Seeds, beans, leaves, fruit peel and seeds of five plants (Ferula assa-foetida, Coffea robusta, Olea europaea, Punica granatum and Vitis vinifera, respectively) were extracted with four solvents (distilled water, $80 \%$ methanol, $80 \%$ acetone and a mixed solvent that included methanol, ethanol, acetone and $\mathrm{n}$ butanol at proportions $7: 1: 1: 1$ ). Such manipulation yielded 20 extracts, which were phytochemically analyzed for total polyphenols (TP) and flavonoids (TF). The DPPH (2,2-diphenyl-1-picrylhydrazyl) radical scavenging activity (RSA) and DPP-4 (dipeptidyl peptidase-4) relative inhibition activity (RIA) were also assessed for each extract. The results revealed that mixed solvent extract of $V$. vinifera seeds showed the highest content of TP $(194.8 \pm 2.5 \mathrm{mg}$ Gallic acid equivalent/g dry mass $)$, while methanol extract of $V$. vinifera seeds recorded the highest content of TF $(75.9 \pm 0.3 \mathrm{mg}$ catechin equivalent/g dry mass). The $C$. robusta bean aqueous extract was remarkable in scoring the highest DPPH RSA $(87.2 \pm 1.2 \%)$, while $O$. europaea leaf methanol extract had the highest DPP-4 RIA $(86.4 \pm 0.8 \%)$. In conclusion, the importance of natural products as radical scavengers and DPP-4 inhibitors is encouraged, and such biological effects were dependent on the plant species and the solvent of extraction. C. robusta beans are suggested to have a prominent RSA, while O. europaea leaves are recommended to be a target for investigations involved in the development of anti-T2DM therapies.
\end{abstract}

Key words: Coffea robusta, DPPH, DPP-4 inhibitors, Ferula assa-foetida, Olea europaea, Punica granatum, Vitis vinifera.

\section{Introduction:}

Type 2 Diabetes mellitus (T2DM) is a global disease and recent estimates have revealed that around $10 \%$ of adults are diabetic, and $90 \%$ of whom are grouped under T2DM (1). It is a progressive chronic metabolic syndrome that is hallmarked by hyperglycemia due to a defect in insulin secretion, insulin action, or beta-cell impairment (2). The disease is complex in terms of etiology and pathogenesis, and several metabolic inflammatory signaling pathways are triggered by the established hyperglycemia. The consequence is cell death (apoptosis) and diabetic complications, which include nephropathy, retinopathy and cardiovascular diseases (3). Oxidative damages mediated by highly reactive free radicals have been depicted to play an important role in these complications, and interplay between diabetes and oxidative stress has been suggested (4).

Hyperglycemia in T2DM is controlled by different oral hypoglycemic agents.

\footnotetext{
${ }^{\mathrm{T}}$ Biotechnology Department, College of Science, University of Baghdad, Baghdad, Iraq.

${ }^{2}$ Tropical-Biological Research Unit, College of Science, University of Baghdad, Baghdad, Iraq.

*Corresponding author: 1ateef230@gmail.com
}

They are classified as enhancers of insulin secretion (sulfonylureas and glinides) or insulin sensitivity like the most abundant drugs (metformin and the thiazolidinediones). A further group includes inhibitors of intestinal carbohydrate absorption (alpha-glucosidase inhibitors) (5). However, these agents have a complex mechanism of action, and they are associated with some adverse effects (hypoglycemia, weight gain, gastrointestinal disturbance, lactic acidosis and fluid retention) (6). Over the last decade, oral hypoglycemic agents that inhibit the enzyme dipeptidyl peptidase-4 (DPP-4) have emerged as an effective and promising therapeutic strategy for the management of T2DM (7).

DPP-4 is a serine protease that cleaves $\mathrm{N}$ terminal dipeptides from polypeptides, and by such pathway, it regulates the bioactivity of many peptides including the two incretin hormones glucagon like peptide -1 (GLP-1) and glucose dependent insulinotropic polypeptide (GIP), which are major regulators of post-prandial insulin secretion (8). GLP-1 has been suggested to have trophic effects on pancreatic $\beta$-cells and has been reported to inhibit glucagon release. Similarly, GIP 
stimulates insulin secretion in a glucose-dependent manner, and in addition to its insulinotropic effect, it also elicits glucagon release (9). In T2DM, a decrease in the incretin effect and rapid degradation of short lived GLP-I and GIP have been reported due to their rapid inactivation by DPP-4, and consequently, GLP-1 and GIP are no longer available in the active form (10). Therefore, an efficient therapy with DPP-4 inhibitors can inactivate the enzyme and prevent the cleavage of GLP-1 and GIP and prolong their half-life and biological activity (7).

Several DPP-4 inhibitors have recently been approved, and these medicines have been reported to have the potential of lowering blood glucose and glycosylated hemoglobin type $\mathrm{A} 1 \mathrm{C}\left(\mathrm{HbA}_{1 \mathrm{c}}\right)$ levels and to improve glucose tolerance in $\mathrm{T} 2 \mathrm{DM}$ patients (11). However, natural products of herbal medicines and their secondary metabolites have increasingly been suggested to treat T2DM and they may have the potential as DPP-4 inhibitors (12); for instance, it has been reported that naringin, a flavanone glycoside of a plant origin, shows a potent inhibiting effect on serum level of DPP-4 (13). Furthermore, plants have been widely recognized as a cardinal source of antioxidant and radical scavenger agents, with increasing evidence that supports their health-promoting properties (14).

Accordingly, the present study was designed to evaluate the in vitro DPP-4 inhibitory potential of five plants (Ferula assa-foetida L., Coffea robusta L., Olea europaea L., Punica granatum L. and Vitis vinifera L.), as well as their radical scavenger activity.

\section{Materials and Methods: \\ Source of materials:}

DPP-4 inhibitor screening kit was purchased from Sigma-Aldrich (Germany). Gallic acid and catechin standards, Folin-Ciocalteu, aluminum trichloride, sodium carbonate, sodium hydroxide, sodium nitrite and DPPH (2,2-diphenyl-1picrylhydrazyl) were products of Merck company (Germany). Methanol, ethanol, acetone and nbutanol were products of BDH (UK).

\section{Raw plant materials:}

Ferula assa-foetida (seeds) and Coffea robusta (beans) were purchased from a local traditional drug store. Punica granatum and Vitis vinifera were purchased from a local market, and their peels and seeds were used, respectively. Olea europaea leaves were collected from a house garden (June, 2017) in Nasiriya. All plant samples were taxonomically identified by the herbarium staff at the Faculty of Agriculture and Marshes (Thi-Qar University).

\section{Preparation of plant extracts:}

The collected plant parts were rinsed with tap-water, and then air-dried in a hot-air oven at $40^{\circ} \mathrm{C}$ for 72 hours. Dried plant parts were pulverized with stainless steel electric grinder, and the powder was stored in a dark tight-sealed glass container at room temperature $\left(20-25^{\circ} \mathrm{C}\right)$. Three grams of each powder were extracted with $30 \mathrm{ml}$ of a solvent. Four solvents were used; distilled water, $80 \%$ methanol (v/v), $80 \%$ acetone (v/v) and a mixed solvent (methanol:ethanol:acetone:n-butanol at proportions 7:1:1:1). Accordingly, 20 extracts were yielded; four extracts (AQ, ME, AC and MX, respectively) for each plant. The plant powder was mixed with the solvent in $50 \mathrm{ml}$ conical flask for 24 hours using a magnetic stirrer at room temperature. The obtained solution was centrifuged (3000 rpm for $15 \mathrm{~min}$.) and the supernatant was collected in petri-dishes, which were transferred to a hot-air oven $\left(40^{\circ} \mathrm{C}\right)$ till the solvent was evaporated. The resulting plant extract layer was scraped from the surface of petri-dishes, collected, weighted and kept in a dark tight-sealed glass container, which was stored at $-20^{\circ} \mathrm{C}$ until experimental use (15).

\section{Determination of total polyphenols:}

Total polyphenols (TP) were determined by the Folin-Ciocalteu (F-C) assay (16). Briefly, 0.5 $\mathrm{mL}$ of each extract $(1.0 \mathrm{mg} / \mathrm{mL})$ or Gallic acid aqueous solutions $(5,10,15,20$ and $25 \mathrm{mg} / \mathrm{mL})$ was mixed with $2.5 \mathrm{~mL}$ of F-C reagent. A minute later, $2.5 \mathrm{~mL}$ of $20 \%$ sodium carbonate $\left(\mathrm{Na}_{2} \mathrm{CO}_{3}\right)$ solution $(\mathrm{w} / \mathrm{v})$ was added, and the mixture was allowed to stand for a further $30 \mathrm{~min}$. in the dark, and the absorbance was measured at a wavelength of $760 \mathrm{~nm}$. A standard curve was plotted and TP was expressed as $\mathrm{mg}$ Gallic acid equivalent per gram of dry mass (mg GE/g DM).

\section{Determination of total flavonoids:}

Total flavonoids (TF) were estimated by a colorimetric method using aluminium chloride $\left(\mathrm{AlCl}_{3}\right)$ and sodium hydroxide $(\mathrm{NaOH})$ assay (15). Briefly, $0.05 \mathrm{~mL}$ of either $1.0 \mathrm{mg} / \mathrm{mL}$ of each extract or catechin standards $(10,20,30,40,50$ and $60 \mathrm{mg} / \mathrm{mL}$ ) were mixed with $2.0 \mathrm{~mL}$ of distilled water, $0.15 \mathrm{~mL}$ of $150 \mathrm{~g} / \mathrm{L}$ sodium nitrite $\left(\mathrm{NaNO}_{2}\right)$ solution, and $0.15 \mathrm{~mL}$ of $100 \mathrm{~g} / \mathrm{L} \mathrm{AlCl}_{3} \cdot 6 \mathrm{H}_{2} \mathrm{O}$ solution. After $6 \mathrm{~min}$., $2.0 \mathrm{~mL}$ of $\mathrm{NaOH}$ solution (mol/L) was added and the volume was made-up to $5.0 \mathrm{~mL}$ with distilled water. The mixture was allowed to stand in dark for $15 \mathrm{~min}$., and the absorbance was measured at a wavelength of $510 \mathrm{~nm}$. A standard curve was plotted and TF was expressed as $\mathrm{mg}$ catechin equivalent per gram of dry mass (mg CE/g DM). 


\section{Antioxidant activity:}

The DPPH radical-scavenging activity (RSA) was adopted to assess the antioxidant activity of extracts in 96-well microplates, as previously described with a slight modification (17). Briefly, two reaction wells were assigned; in the first well, $100 \mu \mathrm{l}$ of plant extract $(500 \mu \mathrm{g} / \mathrm{ml})$ was added (sample-blank), while in the second well, $100 \mu 1$ of $0.2 \mathrm{mmol} / \mathrm{L}$ DPPH solution in 95\% methanol solution was added together with the plant extract as in the first well (sample+DPPH). Solvent $(100 \mu \mathrm{l}$ of 95\% methanol) and DPPH $(100 \mu \mathrm{l}$ of $0.2 \mathrm{mmol} / \mathrm{L}$ DPPH) were also included in a further two wells. Then, the microplate was incubated for $30 \mathrm{~min}$. in the dark at room temperature, and the absorbance was recorded for each well at $517 \mathrm{~nm}$ wavelength using a microplate reader (ELx800 BioTek Instruments Inc .USA). The percentage of DPPH RSA was calculated using the following equation (17):

$$
\text { \% DPPH RSA }=[(\mathrm{A}-\mathrm{B}) /(\mathrm{C}-\mathrm{D}] \times 100
$$

Where A: sample+DPPH absorbance, B: sampleblank absorbance, C: DPPH absorbance, D: solvent absorbance

\section{DPP-4 inhibition screening assay:}

The DPP-4 inhibition screening kit (Catalog Number MAK203, Sigma-Aldrich, Germany) was used to assess the DPP-4-inibitory effect of the plant extracts. The principle of assessment is based on measuring the DPP-4 activity by cleaving the substrate to yield a fluorescent product $\left(\lambda_{\mathrm{ex}}=\right.$ $360 \mathrm{~nm} / \lambda_{\text {em }}=460 \mathrm{~nm}$ ), which is proportional to the enzymatic activity present in the test sample. The effectiveness of the tested inhibitors was compared with a standard DPP-4 inhibitor (sitagliptin) provided with the kit. The instructions of manufacturer were followed, and the DPP-4inhibition activity of extracts was given as percentage of relative inhibition (relative inhibition activity; RIA).

\section{Experimental Design and Statistical analysis:}

An in vitro study was designed to evaluate the potential of some plant extracts (given in section raw plant materials) as DPP-4 inhibitors and radical scavengers after their extraction with different solvents. Data were given as mean \pm standard deviation (SD) of duplicate assessments, and significant difference between means was assessed by Duncan's multiple range test, in which a $p$-value of $\leq 0.01$ was considered significant. Pearson bivariate analysis was also employed to estimate the correlation between investigated parameters. The SPSS software (version 13.0) was used to carry out these analyses.

\section{Results:}

Phytochemical contents, DPPH RSA and DDP-4 RIA (Table 1)

Phytochemical analysis of TP and TF content revealed significant variations between the analyzed plant extracts. For TP, the MX extract of $V$. vinifera seeds showed the highest content $(194.8 \pm 2.5 \mathrm{mg}$ GE/g DM), while a lowest content was recorded in ME extracts of $P$. granatum fruit peel $(101.2 \pm 1.0$ $\mathrm{mg} \mathrm{GE} / \mathrm{g} \mathrm{DM})$. In the case of TF, the ME extract of $V$. vinifera seeds dominated the highest content (75.9 $\pm 0.3 \mathrm{mg} \mathrm{CE} / \mathrm{g} \mathrm{DM})$, which was counteracted by a lowest content $(1.5 \pm 0.1 \mathrm{mg} C E / \mathrm{g} \mathrm{DM})$ in the MX extract of $F$. assa-foetida seeds.

The DPPH RSA was also subjected to a significant variation between the plant extracts. The C. robusta beans AQ extract was remarkable in scoring $87.2 \pm 1.2 \% \mathrm{RSA}$, followed by the AQ extract of $V$. vinifera seeds $(83.2 \pm 1.0 \%)$. A lowest RSA was recorded in the $P$. granatum peel AQ extract $(30.5 \pm 2.1 \%)$.

The assessment of DDP-4 RIA revealed a range of a significant variation that was related to the species of plant and the solvent of extraction, but the four extracts of $O$. europaea leaves (AQ, $\mathrm{ME}, \mathrm{AC}$ and $\mathrm{MX})$ were at the top of list $(73.5 \pm 1.0$, $86.4 \pm 0.8,81.1 \pm 0.6$ and $78.3 \pm 0.8 \%$, respectively). Whereas, $P$. granatum peel MX extract recorded the lowest DDP-4 RIA, which was $28.7 \pm 0.9 \%$. 
Table 1. Phytochemical contents and DPPH radical scavenging and DDP-4 relative inhibition activities of selected plant extracts.

\begin{tabular}{|c|c|c|c|c|c|}
\hline \multirow{2}{*}{$\begin{array}{l}\text { Plant (extracted } \\
\text { part) }\end{array}$} & \multirow[b]{2}{*}{ Solvent } & \multicolumn{4}{|c|}{ Mean \pm SD } \\
\hline & & $\begin{array}{c}\text { Polyphenols } \\
\text { (mg GE/g DM) }\end{array}$ & $\begin{array}{c}\text { Flavonoids } \\
\text { (mg CE/g DM) }\end{array}$ & DPPH RSA (\%) & DPP-4 RIA (\%)• \\
\hline \multirow{4}{*}{$\begin{array}{l}\text { Ferula assa-foetida } \\
\text { (Seeds) }\end{array}$} & $\mathrm{AQ}$ & $121.4 \pm 0.9^{1}$ & $2.5 \pm 0.1^{\mathrm{RS}}$ & $54.0 \pm 0.1^{\mathrm{FG}}$ & $46.0 \pm 1.0^{\mathrm{GHI}}$ \\
\hline & $\mathrm{ME}$ & $160.1 \pm 2.0^{\mathbf{D}}$ & $9.0 \pm 0.2^{\mathrm{K}}$ & $58.4 \pm 2.0^{\mathrm{DE}}$ & $46.4 \pm 0.5^{\mathrm{GHI}}$ \\
\hline & $\mathrm{AC}$ & $166.4 \pm 1.6^{\mathrm{C}}$ & $14.6 \pm 0.4^{\mathrm{F}}$ & $56.6 \pm 0.8^{\mathbf{E F}}$ & $47.4 \pm 0.8^{\mathbf{G H}}$ \\
\hline & MX & $157.2 \pm 2.7^{\mathbf{D E}}$ & $1.5 \pm 0.1^{\mathrm{s}}$ & $47.6 \pm 0.8^{\mathbf{I}}$ & $45.9 \pm 0.4^{\mathrm{HIJK}}$ \\
\hline \multirow{4}{*}{$\begin{array}{c}\text { Coffea robusta } \\
\text { (Beans) }\end{array}$} & $\mathrm{AQ}$ & $148.8 \pm 0.8^{\mathrm{F}}$ & $12.1 \pm 0.5^{\mathrm{GH}}$ & $87.2 \pm 1.2^{\mathrm{A}}$ & $36.5 \pm 1.2^{\mathrm{L}}$ \\
\hline & ME & $154.4 \pm 0.9^{\mathbf{E}}$ & $23.9 \pm 0.2^{\mathrm{E}}$ & $50.6 \pm 0.6^{\mathbf{H}}$ & $46.6 \pm 0.5^{\mathrm{GHI}}$ \\
\hline & $\mathrm{AC}$ & $141.9 \pm 0.3^{\mathbf{G}}$ & $13.3 \pm 0.4^{\mathbf{G}}$ & $68.9 \pm 1.0^{\mathbf{D}}$ & $44.8 \pm 0.3^{\mathrm{HIJ}}$ \\
\hline & MX & $144.7 \pm 1.6^{\mathbf{G}}$ & $11.3 \pm 0.6^{\mathrm{HI}}$ & $68.5 \pm 0.7^{\mathbf{D}}$ & $37.0 \pm 0.2^{\mathbf{L}}$ \\
\hline \multirow{4}{*}{$\begin{array}{l}\text { Olea europaea } \\
\text { (Leaves) }\end{array}$} & $\mathrm{AQ}$ & $121.2 \pm 1.2^{1}$ & $5.9 \pm 0.1^{\mathrm{MN}}$ & $74.2 \pm 1.6^{\mathrm{C}}$ & $73.5 \pm 1.0^{\mathrm{D}}$ \\
\hline & ME & $151.7 \pm 1.5^{\mathrm{EF}}$ & $9.9 \pm 0.1^{\mathrm{JK}}$ & $56.2 \pm 0.2^{\mathbf{E F}}$ & $86.4 \pm 0.8^{\mathbf{A}}$ \\
\hline & $\mathrm{AC}$ & $145.2 \pm 1.8^{\mathbf{G}}$ & $14.3 \pm 0.4^{\mathbf{F}}$ & $41.5 \pm 0.8^{\mathrm{J}}$ & $81.1 \pm 0.6^{\mathbf{B}}$ \\
\hline & MX & $137.0 \pm 1.5^{\mathbf{H}}$ & $10.4 \pm 0.2^{\mathbf{I J}}$ & $54.9 \pm 1.2^{\mathrm{EFG}}$ & $78.3 \pm 0.8^{\mathbf{C}}$ \\
\hline \multirow{4}{*}{$\begin{array}{l}\text { Punica granatum } \\
\text { (Fruit peel) }\end{array}$} & $\mathrm{AQ}$ & $154.7 \pm 1.2^{\mathrm{E}}$ & $3.6 \pm 0.1^{\mathrm{QR}}$ & $30.5 \pm 2.1^{\mathrm{K}}$ & $43.1 \pm 1.4^{\mathrm{K}}$ \\
\hline & $\mathrm{ME}$ & $101.2 \pm 1.0^{\mathrm{J}}$ & $4.8 \pm 0.2^{\mathrm{NO}}$ & $53.6 \pm 0.6^{\mathrm{FGH}}$ & $47.1 \pm 1.5^{\mathbf{G H}}$ \\
\hline & $\mathrm{AC}$ & $159.9 \pm 0.4^{\mathbf{D}}$ & $7.6 \pm 0.2^{\mathrm{L}}$ & $52.0 \pm 0.1^{\mathbf{G H}}$ & $44.0 \pm 0.9^{\mathrm{IJ}}$ \\
\hline & MX & $154.3 \pm 1.5^{\mathrm{E}}$ & $4.3 \pm 0.2^{\mathbf{O P Q}}$ & $54.7 \pm 0.9^{\mathbf{F G}}$ & $28.7 \pm 0.9^{\mathrm{M}}$ \\
\hline \multirow{4}{*}{$\begin{array}{l}\text { Vitis vinifera } \\
\quad \text { (Seeds) }\end{array}$} & $\mathrm{AQ}$ & $186.4 \pm 0.8^{\mathbf{B}}$ & $44.2 \pm 1.3^{\mathbf{D}}$ & $83.2 \pm 1.0^{\mathbf{B}}$ & $48.3 \pm 0.3^{\mathbf{F}}$ \\
\hline & ME & $187.2 \pm 0.5^{\mathbf{B}}$ & $75.9 \pm 0.3^{\mathbf{A}}$ & $53.8 \pm 2.0^{\mathbf{F G}}$ & $51.7 \pm 2.1^{\mathbf{E}}$ \\
\hline & $\mathrm{AC}$ & $187.3 \pm 0.4^{\mathbf{B}}$ & $62.8 \pm 0.2^{\mathbf{B}}$ & $56.4 \pm 0.9^{\mathrm{EF}}$ & $37.2 \pm 0.1^{\mathrm{L}}$ \\
\hline & MX & $194.8 \pm 2.5^{\mathrm{A}}$ & $61.1 \pm 0.5^{\mathrm{C}}$ & $60.9 \pm 0.6^{\mathbf{D}}$ & $39.1 \pm 0.5^{\mathbf{L}}$ \\
\hline
\end{tabular}

AQ: Aqueous, ME: 80\% Methanol, AC: 80\% acetone, MX: Mixed (methanol:ethanol:acetone:n-butanol at proportion 7:1:1:1), GE: Gallic acid equivalent, CE: Catechin equivalent, DM: Dry mass, DPPH: 2,2-diphenyl-1-picrylhydrazyl, RSA: Radical scavenging activity, DPP-4: Dipeptidyl peptidase-4, RIA: Relative inhibition activity. $\bullet$ The inhibition was relative to Sitagliptin inhibition activity $\left(99.5 \%\right.$; $\mathrm{IC}_{50}$ : 57.4). Different superscript letters represent significant difference $(p$-value $\leq 0.01)$ between means in each column (Duncan's multiple range test).

\section{Correlation between investigated parameters:}

Pearson bivariate analysis showed some significant positive and negative correlations between phytochemical contents, DPPH RSA and DDP-4 RIA of investigated plants. Among F. assafoetida seed extracts, TF showed a significant correlation with DPPH RSA $(r=0.741)$ and DPP-4 RIA ( $\mathrm{r}=0.770)$. Whereas, the $\mathrm{TF}$ of $C$. robusta beans extracts was observed to have a negative correlation with DPPH RSA $(\mathrm{r}=-0.811)$ and a positive correlation with DPP-4 RIA $(r=0.759)$. A similar negative correlation was observed between TP and TF of $O$. europaea leaf extracts and DPPH RSA ( $r=-0.769$ and -0.992 , respectively). However, the TP of the same extracts showed a positive correlation with DPP-4 RIA $(r=0.961)$. The negative correlation between TF and DPPH RSA was also obvious in the extracts of $V$. vinifera seeds $(\mathrm{r}=-0.932)$. Finally, there was no correlation between phytochemicals of $P$. granatum peel extracts and DPPH RSA and DPP-4RIA (Table 2). 
Table 2. Pearson bivariate correlation between phytochemical contents and DPPH radical scavenging and DDP-4 relative inhibition activities of selected plants.

\begin{tabular}{|c|c|c|c|c|}
\hline Parameter & Polyphenols & Flavonoids & DPPH RSA & DPP-4 RIÀ \\
\hline \multicolumn{5}{|c|}{ Ferula assa-foetida (Seeds) } \\
\hline Polyphenols & 1.000 & & & \\
\hline Flavonoids & 0.631 & 1.000 & & \\
\hline DPPH RSA & 0.138 & $0.741 *$ & 1.000 & \\
\hline DPP-4 RIA & 0.433 & $0.770 *$ & 0.512 & 1.000 \\
\hline \multicolumn{5}{|c|}{ Coffee robusta (Beans) } \\
\hline Polyphenols & 1.000 & & & \\
\hline Flavonoids & $0.799 *$ & 1.000 & & \\
\hline DPPH RSA & -0.416 & $-0.811 *$ & 1.000 & \\
\hline DPP-4 RIA & 0.266 & $0.759 *$ & $-0.776^{*}$ & 1.000 \\
\hline \multicolumn{5}{|c|}{ Olea europaea (Leaves) } \\
\hline Polyphenols & 1.000 & & & \\
\hline Flavonoids & 0.710 & 1.000 & & \\
\hline DPPH RSA & $-0.769 *$ & $-0.992 * *$ & 1.000 & \\
\hline DPP-4 RIA & $0.961 * *$ & 0.531 & -0.605 & 1.000 \\
\hline \multicolumn{5}{|c|}{ Punica granatum (Fruit peel) } \\
\hline Polyphenols & 1.000 & & & \\
\hline Flavonoids & 0.183 & 1.000 & & \\
\hline DPPH RSA & -0.303 & 0.496 & 1.000 & \\
\hline DPP-4 RIA & -0.472 & 0.272 & -0.245 & 1.000 \\
\hline \multicolumn{5}{|c|}{ Vitis vinifera (Seeds) } \\
\hline Polyphenols & 1.000 & & & \\
\hline Flavonoids & 0.094 & 1.000 & & \\
\hline DPPH RSA & -0.230 & $-0.932 * *$ & 1.000 & \\
\hline DPP-4 RIA & -0.480 & 0.110 & 0.254 & 1.000 \\
\hline
\end{tabular}

DPPH: 2,2-diphenyl-1-picrylhydrazyl, RSA: Radical scavenging activity, DPP-4: Dipeptidyl peptidase-4, RIA: Relative inhibition activity. *Correlation is significant at the 0.05 level (2-tailed). **Correlation is significant at the 0.01 level (2-tailed).

\section{Discussion:}

Although, the TP and TF contents of investigated extracts showed a great variation, which was related to the plant parts and species and the solvent of extraction, most extracts displayed some richness in these two important phytochemicals, especially $V$. vinifera seed MX and ME extracts, which had the highest content of TP and TF, respectively. Such findings are in a good agreement with most investigators, who demonstrated that $V$. vinifera is a fruit rich in $\mathrm{PF}$ and contains phytochemicals that promote health and different biological activities. In addition, its seeds also have been described to contain several PF that may act as potent antioxidants (18). Polyphenols possess a wide range of biological activities, especially their remarkable antioxidant activity, which is also shared by flavonoids that represent the largest group of naturally occurring polyphenols (19). Therefore, it might have been expected that the present 20 extract showed a good DPPH RSA that ranged between $30.5 \pm 2.1 \%(P$. granatum peel AQ extract) and $87.2 \pm 1.2 \%$ ( $C$. robusta bean AQ extract). However, the Pearson bivariate analysis of correlation between TP or TF and DPPH RSA showed a dichotomous picture. In the first, a positive correlation between $F$. assafoetida seed TF and DPPH RSA was noticed, while in contrast, $C$. robusta bean, O. europaea leaf and $V$. vinifera seed $\mathrm{TF}$ showed a negative correlation. This may suggest that the action on RSA is not limited to TP and TF in the extracts, and other phytochemicals in the extracts may interfere with such action and the extract RSA is the outcome of synergistic effects of different phytochemicals present in extracts. It has been recently discussed that bioactive phytochemicals and their secondary metabolites of plants can produce synergistic effects, but it is difficult to reveal the mechanisms that are responsible for the synergistic RSA due to the complex nature of plant extracts. Therefore, such scope will be better understood if different natural antioxidants are subjected to standardization and optimization (20).

In addition to RSA, DPP-4 inhibition potentials of the plant extracts were examined, and although no positive correlation between $\mathrm{TP}$ or TF and DPP-4 RIA was recorded (O. europaea was an exception), some of the extracts can be considered as potent DPP-4 inhibitors, especially the four leaf extracts of $O$. europaea, which recorded DPP-4 RIA that exceeded $70 \%$. Moreover, a highly significant positive correlation between the plant TP and DPP-4 RIA was recorded $(\mathrm{r}=0.961)$; an observation that suggests the potent importance of such extract in the treatment of T2DM. In 
agreement with such suggestion, it has been demonstrated that $O$. europaea leaf polyphenols supplemented as capsules for overweight middleaged men for 12 weeks was associated with a significant improvement in insulin sensitivity and secretory capacity of pancreatic $\beta$-cells (21). Diet rich in oleuropein (a phenolic compound abundantly found in O. europaea leaves) was also able to attenuate hyperglycemia and impaired glucose tolerance in mouse model of T2DM (22). A further evidence has presented that oleuropein was associated with a promotion of glucose-stimulated insulin secretion in $\beta$-cells (23). Such effects of polyphenols on modulating T2DM parameters may be due to their interaction with DPP-4, and the present study revealed a substantial inhibition of such enzyme by $O$. europaea leaf extracts, which are rich in polyphenols. In this context, it has been described that the polyphenol-anti-diabetic action is related to the secretion and effects of GLP-1, which is an enteric hormone involved in stimulating postprandial insulin secretion. Furthermore, it is also evident that polyphenols from various plant sources are able to stimulate GLP-1 secretion from L-cells and increase its half-life by inhibiting DPP-4 (24).

In conclusion, the present study confirms the importance of natural products as radical scavengers and DPP-4 inhibitors, and such biological effects are dependent on the plant species and solvent of extraction. $C$. robusta beans are suggested to have a prominent RSA, while $O$. europaea leaves are recommended to be a target for investigations involved in the development of anti-T2DM therapies.

\section{Acknowledgments}

The authors appreciate the cooperation of the herbarium staff at the Faculty of Agriculture and Marshes (Thi-Qar University).

\section{Conflicts of Interest: None.}

\section{References:}

1. Zheng Y, Ley SH, Hu FB. Global aetiology and epidemiology of type 2 diabetes mellitus and its complications. Nat Rev Endocrinol. 2017;14(2):8898.

2. American Diabetes Association. Diagnosis and classification of diabetes mellitus. Diabetes Care. 2009;31(Suppl 1):S62-S67.

3. Hameed I, Masoodi SR, Mir SA, Nabi M, Ghazanfar K, Ganai BA. Type 2 diabetes mellitus: from a metabolic disorder to an inflammatory condition. World J Diabetes. 2015;6(4):598-612.

4. Asmat U, Abad K, Ismail K. Diabetes mellitus and oxidative stress-A concise review. Saudi Pharm J SPJ Off Publ Saudi Pharm Soc. 2016;24(5):547-53.
5. Levetan C. Oral antidiabetic agents in type 2 diabetes. Curr Med Res Opin. 2007;23(4):945-52.

6. Tara J, Shrestha M, Shrestha H, Prajapati M, Karkee A, Maharjan A, et al. Adverse effects of oral hypoglycemic agents and adherence to them among patients with type 2 diabetes mellitus in Nepal. J. Lumbini. Med. Coll. 2017;5(1):34-40.

7. Mulvihill EE. Dipeptidyl peptidase inhibitor therapy in type 2 diabetes: control of the incretin axis and regulation of postprandial glucose and lipid metabolism. Peptides. 2018;100:158-64.

8. Röhrborn D, Wronkowitz N, Eckel J. DPP4 in diabetes. Front Immunol. 2015;6:386.

9. Lacroix IME, Li-Chan ECY. Food-derived dipeptidyl-peptidase IV inhibitors as a potential approach for glycemic regulation - Current knowledge and future research considerations. Trends Food Sci Technol. 2016;54:1-16.

10. Papaetis GS. Incretin-based therapies in prediabetes: Current evidence and future perspectives. World J Diabetes. 2014;5(6):817.

11. Ji X, Xia C, Wang J, Su M, Zhang L, Dong T, et al. Design, synthesis and biological evaluation of 4fluoropyrrolidine- 2- carbonitrile and octahydrocyclopenta[b]pyrrole-2-carbonitrile derivatives as dipeptidyl peptidase IV inhibitors. Eur J Med Chem. 2014;86:242-56.

12. Xu L, Li Y, Dai Y, Peng J. Natural products for the treatment of type 2 diabetes mellitus: Pharmacology and mechanisms. Pharmacol Res. 2018;130:451-65.

13. Parmar HS, Jain P, Chauhan DS, Bhinchar MK, Munjal V, Yusuf M, et al. DPP-IV inhibitory potential of naringin: an in silico, in vitro and in vivo study. Diabetes Res Clin Pract. 2012;97(1):105-11.

14. Guesmi F, Ben Hadj AS, Landoulsi A. Investigation of extracts from Tunisian ethnomedicinal plants as antioxidants, cytotoxins, and antimicrobials. Biomed Environ Sci. 2017;30(11):811-24.

15. Miliauskas G, Venskutonis PR, van Beek TA. Screening of radical scavenging activity of some medicinal and aromatic plant extracts. Food Chem. 2004;85(2):231-7.

16. Singleton VL, Orthofer R, Lamuela-Raventós RM. Analysis of total phenols and other oxidation substrates and antioxidants by means of folinciocalteu reagent. Methods Enzymol. 1999;299:15278 .

17. Vaz JA, Barros L, Martins A, Santos-Buelga C, Vasconcelos MH, Ferreira ICFR. Chemical composition of wild edible mushrooms and antioxidant properties of their water soluble polysaccharidic and ethanolic fractions. Food Chem. 2011;126(2):610-6.

18. Xia E-Q, Deng G-F, Guo Y-J, Li H-B. Biological activities of polyphenols from grapes. Int $\mathbf{J}$ Mol Sci. 2010;11(2):622-46.

19. Sulaiman C, Balachandran I. Total phenolics and total flavonoids in selected Indian medicinal plants. Indian J Pharm Sci. 2012;74:258.

20. Sonam K, Guleria S. Synergistic antioxidant activity of natural products. Ann Pharmacol Pharm. 2017;2(16):1-6.

21. de Bock M, Derraik JGB, Brennan CM, Biggs JB, 
Morgan PE, Hodgkinson SC, et al. Olive (Olea europaea L.) leaf polyphenols improve insulin sensitivity in middle-aged overweight men: a randomized, placebo-controlled, crossover trial. PLoS One. 2013;8(3):e57622.

22. Murotomi K, Umeno A, Yasunaga M, Shichiri M, Ishida N, Koike $\mathrm{T}$, et al. Oleuropein-rich diet attenuates hyperglycemia and impaired glucose tolerance in type 2 diabetes model mouse. J Agric
Food Chem. 2015;63(30):6715-22.

23. Wu L, Velander P, Liu D, Xu B. Olive component oleuropein promotes $\beta$-Cell insulin secretion and protects $\beta$-cells from amylin amyloid-induced cytotoxicity. Biochemistry. 2017;56(38):5035-9.

24. Avila JAD, García JR, Aguilar GAG, De La Rosa LA. The antidiabetic mechanisms of polyphenols related to increased glucagon-like peptide-1 (GLP1) and insulin signaling. Molecules. 2017;22(6):1-16.

\section{قابلية بعض المستخلصات النباتية على اقتناص الجذور الحرة و تثبيط أنزيم ثنائي بييتايديل بيبتايديز-4)}

\section{(DPP-4)}

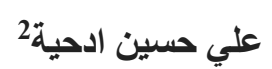

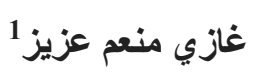

\section{لطيف عبدالكاظم مالك 1}

21 - قسم التقانات الأحيائية، كلية العلوم، جامعة بغداد. 2 وحدة الابحاث البايولوجية للمناطق الحارة، كلية العلوم، جامعة بغداد.

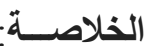

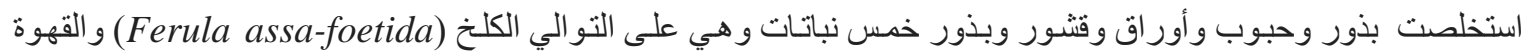

(Coffea robusta) و الزيتون (Olea europaea) و والرمان (Punica granatum) و والعنب (Vitis vinifera) باستخدام أربع مذيبات

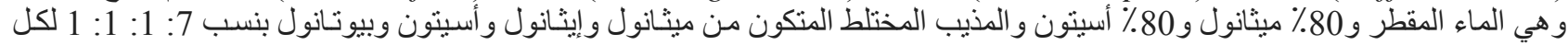

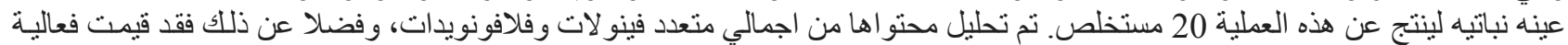

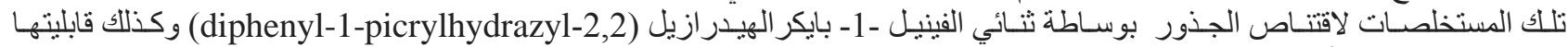

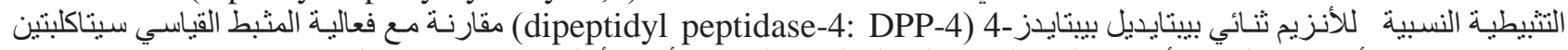
(Sitagliptin) لذور العas

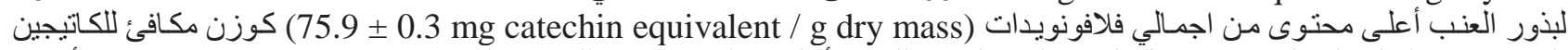

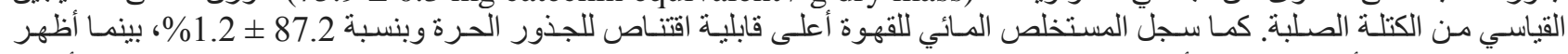

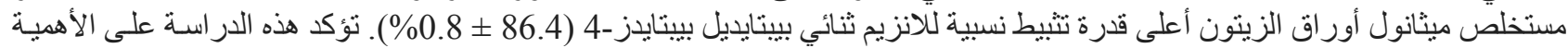

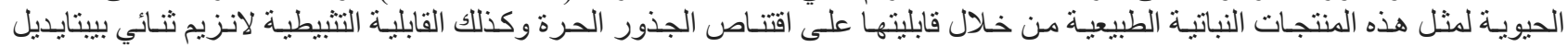

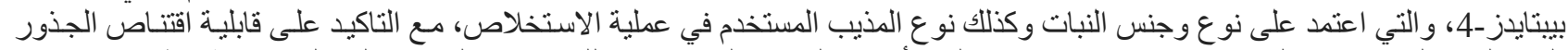

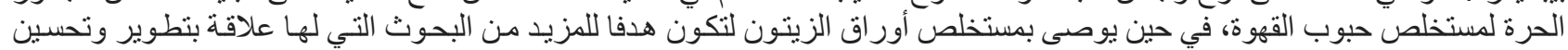
العلاجات المضادة لداء السكري النوع الثناني.

\footnotetext{
الكلمات المفتاحية: الكلخ، القهوة، الزينون، الرمان، العنب، تثبيط، انزيم داي بييتايديل بييتايديز-4، دايفينيل بايكريل هيدرازيل، جذور حرة.
} 